Transactions of the VŠB - Technical University of Ostrava, Mechanical Series

No. 1, 2018, vol. LXIV

article No. 2038

Vojtěch DYBALA*, Martin LIBENSKÝ ${ }^{* *}$, Bohumil ŠULC ${ }^{* *}$, Cyril OSWALD $^{* *}$

\title{
SLIP AND ADHESION IN A RAILWAY WHEELSET SIMULINK MODEL PROPOSED FOR DETECTION DRIVING CONDITIONS VIA NEURAL NETWORKS
}

\section{SKLUZ A ADHEZE V SIMULINK MODELU ŽELEZNIČNÍHO DVOJOKLÍ NAVRŽENÉHO K DETEKCI JÍZDNÍCH PODMÍNEK POMOCÍ NEURONOVÝCH SÍTÍ}

\begin{abstract}
Constantly enlarging operation of locomotives with a very high tractive power in modern railway transport has caused problems with optimal supplying torque from motor to wheelsets. Losses emerging with inadequate torque values lead to wheel slipping connected with excessive wear and limited acceleration. In models simulating dynamics of torque transmission from the drive units to wheels, the most important are the submodel of the drive and the submodel of balance between traction forces and drive resistances. Some issues of this field studied within a PhD program and SGS (CTU Students Grant Competition) has been focused on increasing quality of these submodels. This contribution is aimed at an innovated part in the existing Simulink model utilizing new data sources and modeling techniques. This improvement supports application of operating point detection methods based on machine learning techniques. New control facilities provided with pulse-width modulated frequency control of the asynchronous motor will be used for automatic submission of optimal operating points. The idea of utilization of via simulation obtained data is an on-line training of polynomial neural unit as an approximation of current driving conditions.
\end{abstract}

\begin{abstract}
Abstrakt
Neustále narůstající provoz lokomotiv s velmi vysokým trakčním výkonem v moderní železniční dopravě způsobuje problémy s přenosem optimálního hnacího momentu z motoru na dvojkolí. Ztráty vyplývající z nevhodných hodnot točivého momentu vedou k prokluzu kol spojeným s nadměrným opotřebením a omezeným zrychlením. V modelech simulujících dynamiku přenosu točivého momentu z pohonné jednotky na dvojkolí jsou nejdůležitější submodely pohonu a rovnováhy mezi trakčními silami a jízdními odpory. Výzkum prováděný v rámci doktorských studijních programů a SGS (Studentská grantová soutěž ĆVUT) se zaměřuje na zvyšování kvality těchto submodelů. Tento př́spěvek je zaměřen na inovovanou část v existujícím Simulink modelu využívajícím nové zdroje dat a technik modelování. Nové možnosti regulace zajištěné pulzně-šířkovou frekvenční regulací asynchronního motoru budou použity pro automatické poskytnutí optimálních provozních bodů. Představa využití simulací získaných dat je on-line učení polynomické neuronové jednotky jako aproximace současných jízdních podmínek.
\end{abstract}

* Ing., Department of Automotive, Combustion Engines and Railway Engineering, Faculty of Mechanical Engineering, CTU in Prague, Technická 4, Prague, tel. (+420) 736440 271, e-mail vojtech.dybala@fs.cvut.cz

${ }^{*}$ Bc., Department of Instrumentation and Control Engineering, Faculty of Mechanical Engineering, CTU in Prague, Technická 4, Prague, tel. (+420) 774324 885, e-mail martin.libensky@fs.cvut.cz

*** prof. Ing., CSc., Department of Instrumentation and Control Engineering, Faculty of Mechanical Engineering, CTU in Prague, Technická 4, Prague, tel. (+420) 22435 2531, e-mail bohumil.sulc@fs.cvut.cz

** Ing., Ph.D., Department of Instrumentation and Control Engineering, Faculty of Mechanical Engineering, CTU in Prague, Technická 4, Prague, e-mail cyril.oswald@fs.cvut.cz 


\section{Keywords}

Matlab Simulink, wheel-slip, simulation, Popovici, Polach, adhesion, railway, wheel-set

\section{INTRODUCTION}

As the abstract already mentions, the development in the previous decades has enabled to install twice or more tractive power in vehicles e. g. locomotives in comparison with those, which were designed in 1970's or 1980's. For example in Fig. 1 presented photo of a locomotive Škoda 109E with 6, $4 \mathrm{MW}$ of continuous power belonging into the group of powerful locomotives where danger of a wheel slip on the axle during operation depicted in Fig. 2 could occur as it was detected by another producer.

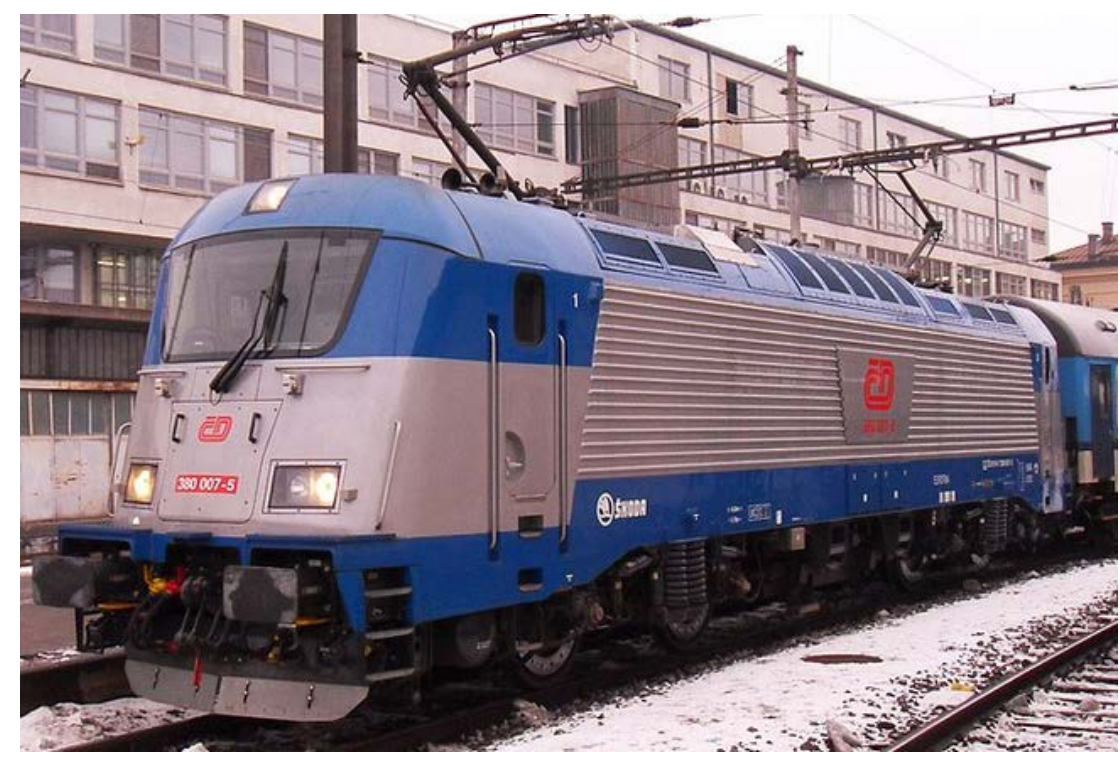

Fig. 1 Locomotive ŠKODA 109E, Pcont = 6,4 MW

That is why we participate in problematics of tractive torque transmission using simulation as a tool for revealing some consequences focused on

- detecting an inadequate tractive torque leading into an inadequate wheel slip and a subsequent limiting vehicle dynamics

- circumstances having influence on occurrence of torsion oscillations

- ways of defining and automatic preserving an optimal operating state respecting outer weather conditions 

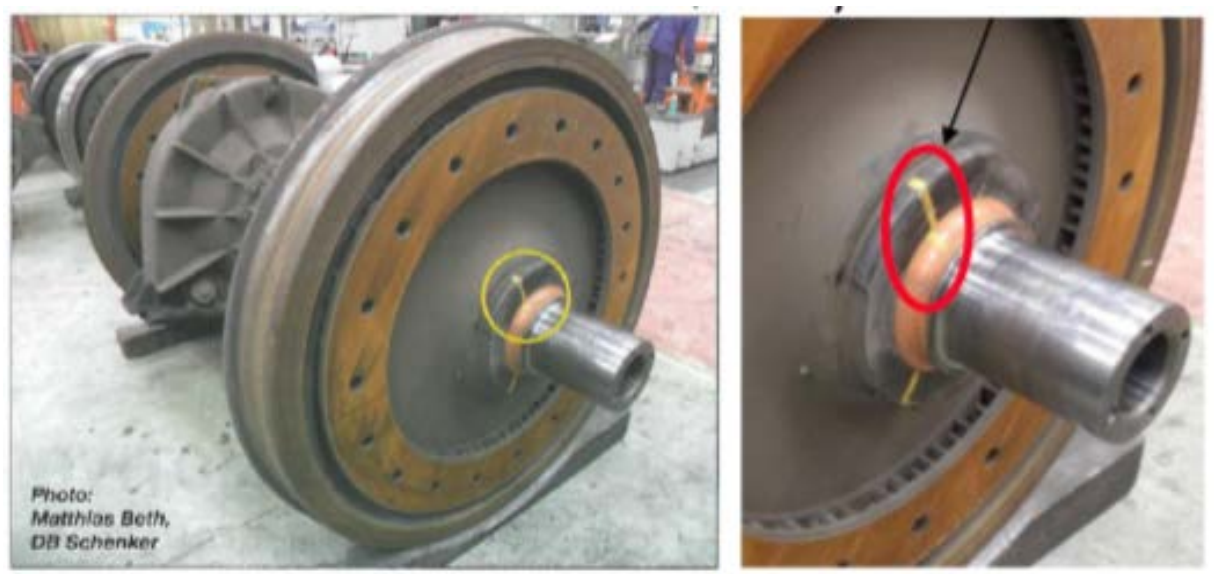

Fig. 2 Slip of a wheel on an axle [3]

\section{SIMULATION MODEL}

Several years ago within PhD study programs at the CTU with a support of student grant competition a simulation model of one of four wheel-sets each driven by the asynchronous motor used in the locomotive Škoda 109E has been designed. The primary purpose of the simulation carried out in Simulink was to detect occurrence, reasons and scale of extensions of torsion oscillations in the wheel-set. Some conclusion from this investigation can be found in [3]. A structure showing main blocks of the model depicted in Fig. 3 has been kept in a continuation of this problematics study presented in this paper.

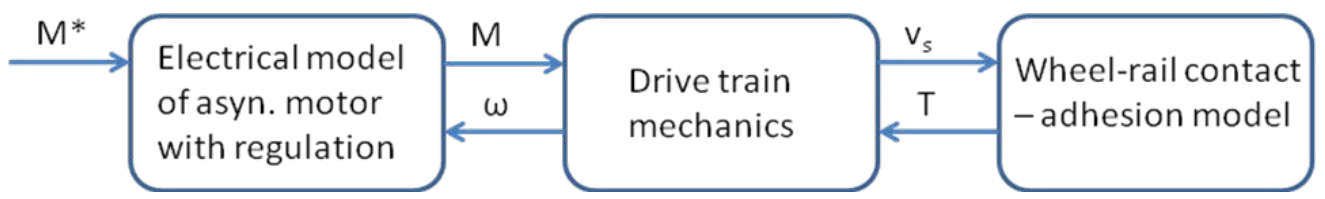

Fig. 3 Block scheme of the simulation model components

In Fig. 3 are presented three basic submodels (Electrical model of the asynchronous motor with its control structure, Drive train mechanics and Wheel-rail contact and adhesion model) and their relations $\left(\mathrm{M}^{*}, \mathrm{M}, \omega, \mathrm{v}_{\mathrm{s}}, \mathrm{T}\right)$.

where:

$M^{*}$ - adjustable torque $[\mathrm{Nm}]$,

$M$ - generated torque [Nm],

$\omega$ - angular speed $[\mathrm{rad} / \mathrm{s}]$,

$v_{S}$ - vehicle velocity $[\mathrm{m} / \mathrm{s}]$,

$T$ - tractive force [N],

Whilst the part serving as a model of drive train mechanics fulfils simulation expectations up to now, the other two blocks have been adapted in order to improve credibility and to open new possibilities in utilizing the model. This is described in the following text. 


\subsection{The Electrical model of the asynchronous motor with control}

The control structure, which is nowadays in use, can be observed in Fig. 4. The asynchronous motor, marked as ASM, is supplied by sinus voltage. The mathematical model of the motor is described by equations below. The red highlighted part of the scheme represents an inverter. Its model is under development and will help to bring the complete model much more closer to the real locomotive regulation structure.

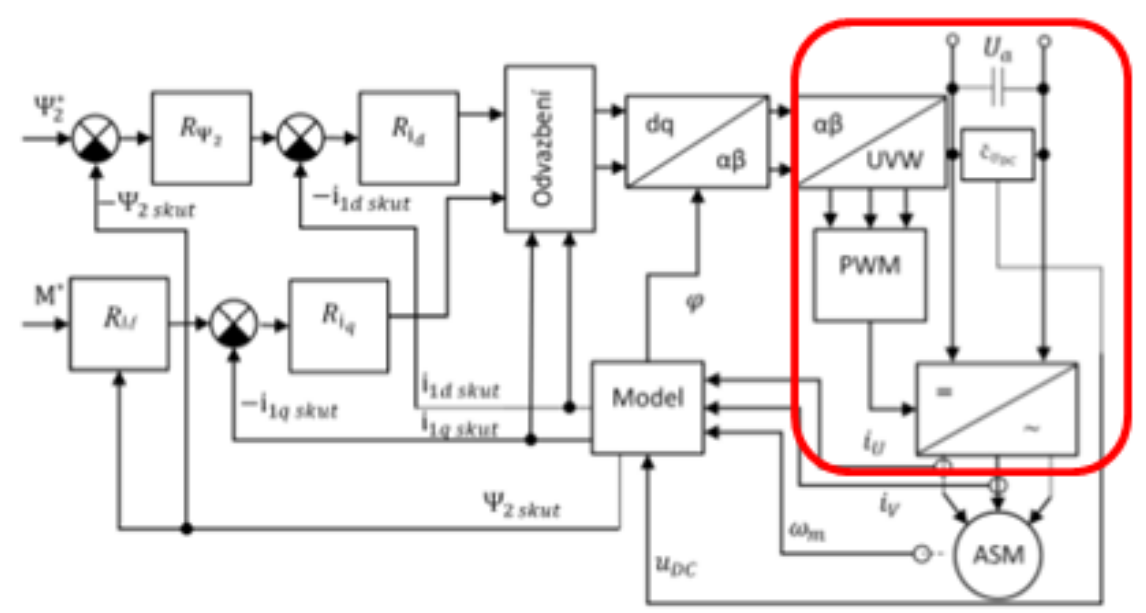

Fig. 4 The structure of vector control in Cartesian coordinates

The mathematical model of the asynchronous motor:

$$
\begin{aligned}
& u_{1 \alpha}(t)=R_{1} i_{1 \alpha}(t)+\frac{d \Psi_{1 \alpha}(t)}{d t} \\
& u_{1 \beta}(t)=R_{1} i_{1 \beta}(t)+\frac{d \Psi_{1 \beta}(t)}{d t} \\
& u_{2 \alpha}(t)=R_{2} i_{2 \alpha}(t)+\frac{d \Psi_{2 \alpha}(t)}{d t}+p_{p} \omega_{m} \Psi_{2 \beta}(t)=0 \\
& u_{2 \beta}(t)=R_{2} i_{2 \beta}(t)+\frac{d \Psi_{2 \beta}(t)}{d t}+p_{p} \omega_{m} \Psi_{2 \alpha}(t)=0 \\
& \Psi_{1 \alpha}(t)=L_{1} i_{1 \alpha}(t)+L_{h} i_{2 \alpha}(t) \\
& \Psi_{1 \beta}(t)=L_{1} i_{1 \beta}(t)+L_{h} i_{2 \beta}(t) \\
& \Psi_{2 \alpha}(t)=L_{2} i_{2 \alpha}(t)+L_{h} i_{1 \alpha}(t) \\
& \Psi_{2 \beta}(t)=L_{2} i_{2 \beta}(t)+L_{h} i_{1 \beta}(t) \\
& M(t)=\frac{3}{2} p_{p}\left(i_{1 \beta}(t) \Psi_{1 \alpha}(t)-i_{1 \alpha}(t) \Psi_{1 \beta}(t)\right)
\end{aligned}
$$


Where:

$u_{1 \alpha}, u_{1 \beta}-$ stator voltages [V],

$i_{l \alpha}, i_{l \beta}$ - stator currents [A],

$\psi_{l \alpha}, \psi_{l \beta}-$ stator magnetic fluxes [Wb],

$R_{1}$ - stator resistance $[\Omega]$,

$L_{1}$ - stator inductance [H],

$u_{2 \alpha}, u_{2 \beta}$ - rotor voltages [V],

$i_{2 \alpha}, i_{2 \beta}$-rotor currents [A],

$\psi_{2 \alpha}, \psi_{2 \beta}$ - rotor magnetic fluxes [Wb],

$R_{2}$ - rotor resistance $[\Omega]$,

$L_{2}$ - stator inductance [H],

$p_{p}$ - number of pole pairs [1],

$\omega_{m}-$ mechanical angular speed of rotor $[\mathrm{rad} / \mathrm{s}]$,

$L_{h}$ - mutual inductance [H],

$M$ - electromagnetic torque $[\mathrm{Nm}]$,

\subsection{The Dynamics model of the drive train mechanics}

A cross section view of all components taking part in transmission of the torque from the motor to the wheels (traction motor, gearbox, clutches, hollow shaft, axle and wheels) is shown in Fig. 5.

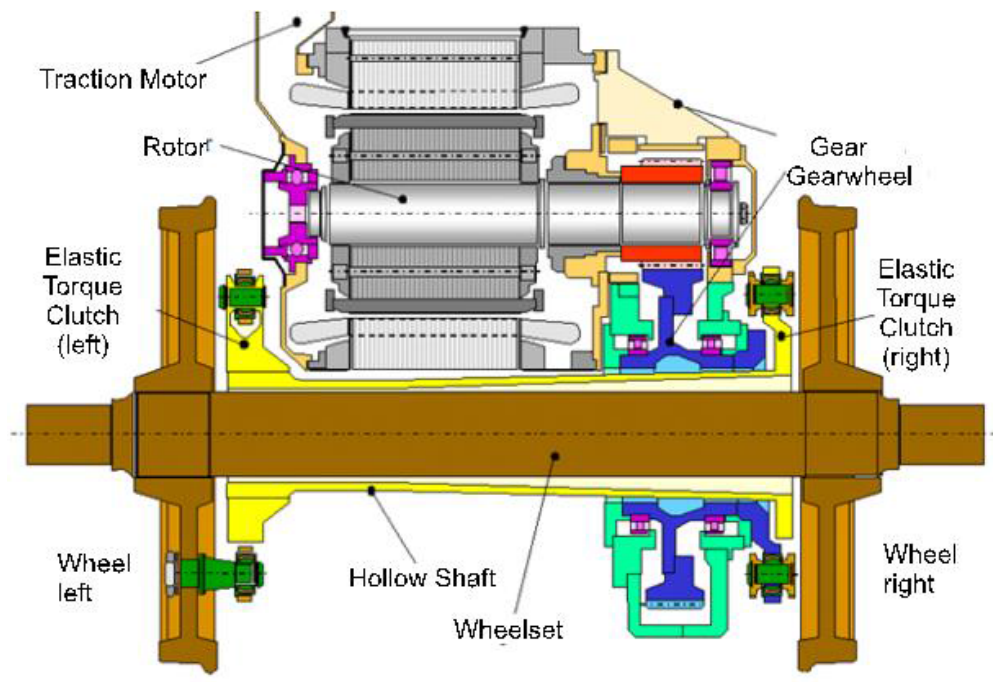

Fig. 5 Cross section of a wheel-set drive

In modelling of dynamics in this transmission, a substitution has been used in which to each technical component has been assigned fictive elements representing separately all main physical phenomena 
participating in this transmission. These elements represent following physical properties: moments of inertia, torsional stiffness and torsional damping. The phenomena can be graphically represented by means of graphic tags recalling simple elements having prevailing properties corresponding to the phenomenon they should represent. Example of such representation is in Fig. 6, where the symbol of a spring represents the torsional stiffness, the symbol of a damper stands for the torsional damping and the wheel moment of inertia is depicted as a rotating disk.

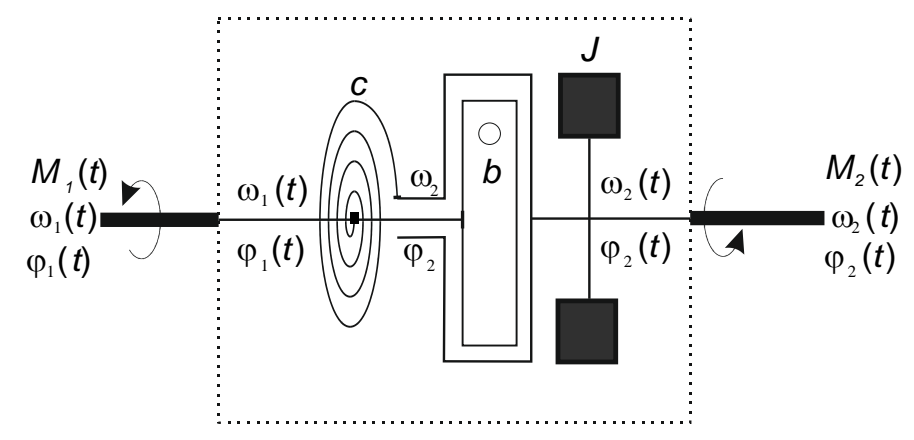

Fig. 6 Substitute schematic concept displaying continuously distributed properties of single components

The composition of these elements depicted in Fig. 6 is described by set of equations

$$
\begin{aligned}
J \dot{\omega}_{2}(t) & =M_{1}(t)-M_{2}(t)= \\
& =b\left(\dot{\varphi}_{1}(t)-\dot{\varphi}_{2}(t)\right)-c\left(\varphi_{1}(t)-\varphi_{2}(t)\right)-M_{2}(t)
\end{aligned}
$$

Where:

$J$ - moment of inertia $\left[\mathrm{kgm}^{2}\right]$,

$\dot{\omega}_{2}$ - output angular acceleration $\left[\mathrm{rads}^{-2}\right]$,

$M_{1}(t)$ - input torque [Nm],

$M_{2}(t)$ - output torque [Nm],

$b$ - torsional damping [Nm],

$\dot{\varphi}_{1}(t)$ - input angular speed [rads ${ }^{-1}$ ],

$\dot{\varphi}_{2}(t)$ - output angular speed [rads ${ }^{-1}$ ],

$c$ - torsional stiffness [ $\left.\mathrm{Nmrad}^{-1}\right]$,

$\varphi_{1}(t)$ - input angle [rad],

$\varphi_{2}(t)$ - output angle [rad ${ }^{1}$,

or by means of the block scheme (Fig. 7). 


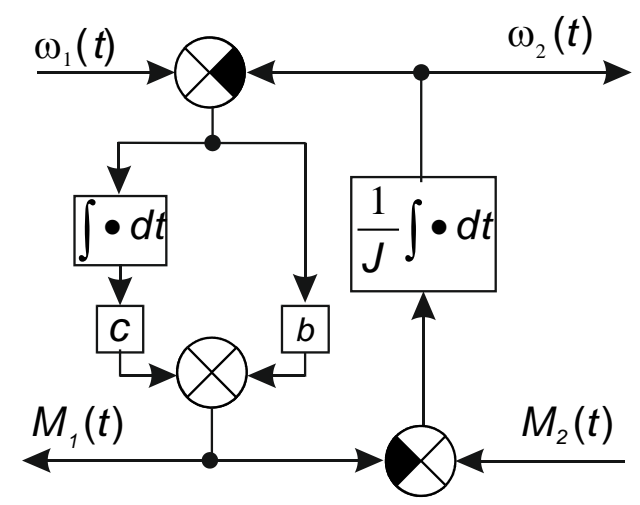

Fig. 7 Block scheme of the system representation of a component in the modelled wheel torque transmission

Dynamic replacement of all wheel-set components (traction motor, gearbox, clutches, hollow shaft, axle and wheels) by such fictive elements has been done intuitively. Result can be seen in Fig. 8.

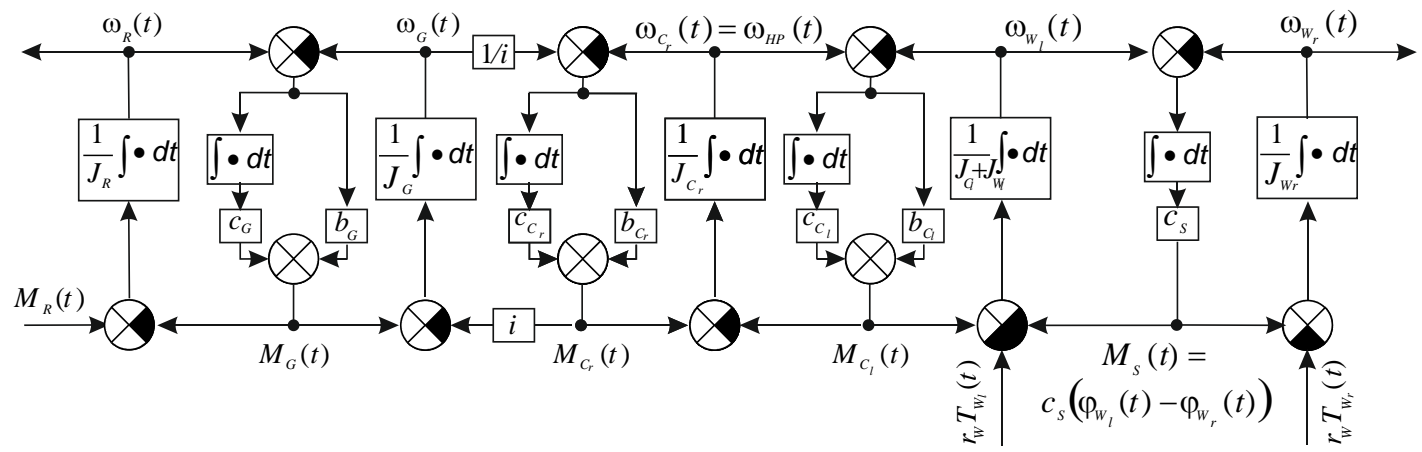

Fig. 8 A block representation of the system modelling dynamics of torque transmission in a simplified (idealized) way using compartment separation of basic physical phenomena

\subsection{Wheel-rail contact and adhesion model}

The wheel-rail contact is the interface where some interactions between the vehicle and the railway infrastructure take place. As a result of these interactions, specific forces arise, shown on the Fig. 9. For our investigation and modeling the longitudinal force $T_{1}$, which represents a traction force is important.

$$
T_{1}=Q \mu
$$

where:

$T_{1}$ - longitudinal force (traction/braking) $[\mathrm{N}]$,

$Q$ - vertical wheel force [N],

$\mu$ - coefficient of adhesion [1], 


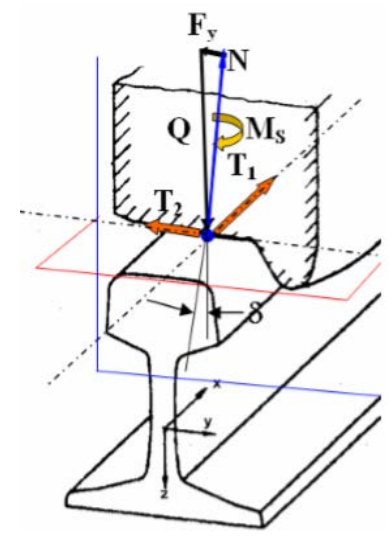

Fig. 9 Forces in the rail-wheel contact [6]

The $T_{1}$ force arises by so called adhesion way. It is typical that the formation of a tangential force is conditioned by an existence of a slip $s$. The slip expresses a difference between circumferential speed of a wheel and a speed of a vehicle. The slip can be defined by the equation (12).

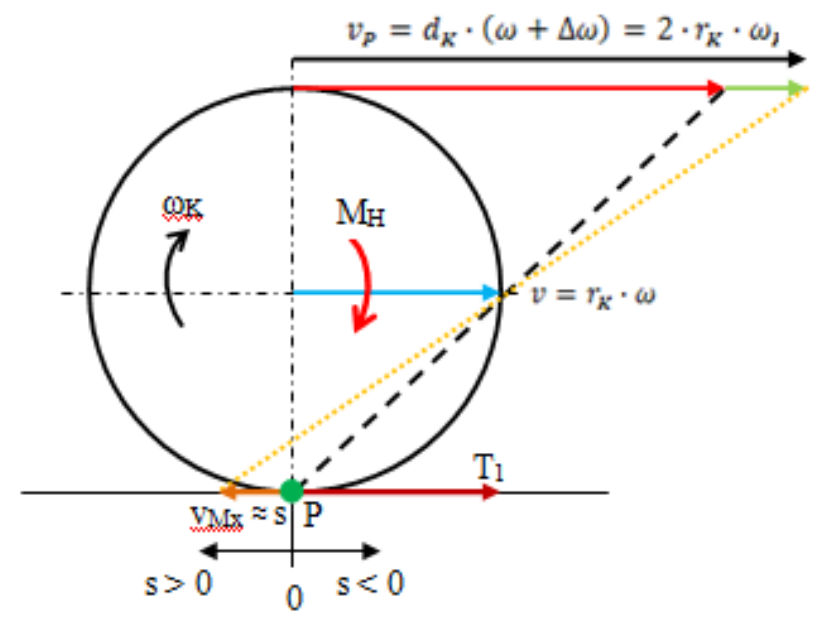

Fig. 10 Visualisation of the wheel slips.

$$
s=\frac{r_{k} \omega_{k}-v}{v}
$$

where:

$s$ - wheel slip [\%],

$r_{k}$ - wheel radius [m],

$\omega_{k}$ - angular speed of a wheel $[\mathrm{rad} / \mathrm{s}]$,

$v$ - vehicle velocity $[\mathrm{m} / \mathrm{s}]$, 
The slip $s$ is an important parameter for definition of the coefficient of adhesion $\mu$. The coefficient of adhesion is also strongly dependent on the wheel-rail contact condition like pollution or weather influence. In these days, there are available many models, which define dependency of the coefficient of adhesion on the slip and service conditions. These models can be separated into two basic groups:

- theoretical models, which are based on applying physical laws and their mathematical formulations that describes the phenomenon; they are used for approximation of the coefficient of adhesion

- empirical characteristics, which are based on measured data obtained both in laboratories or in the real service of real vehicles

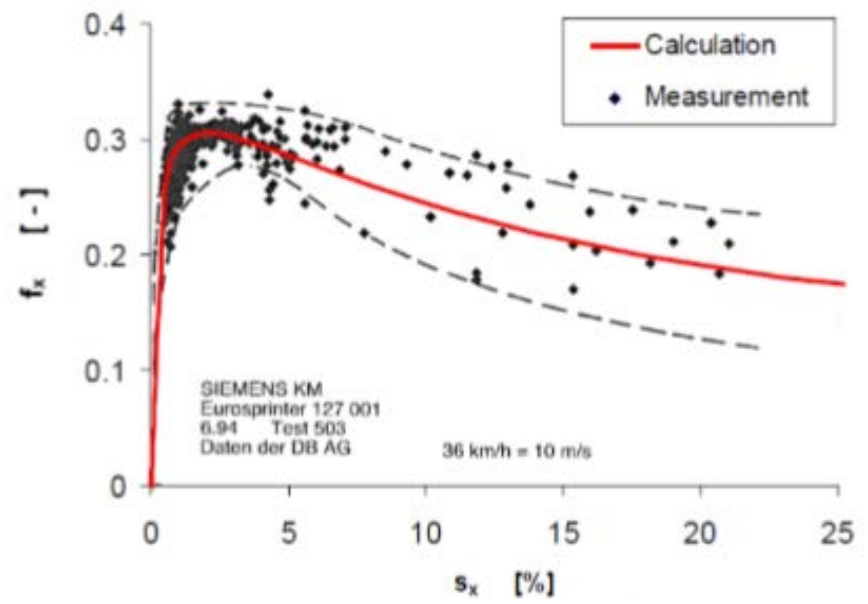

Fig. 11 Example of theoretical characteristic - Polách's theory [5]

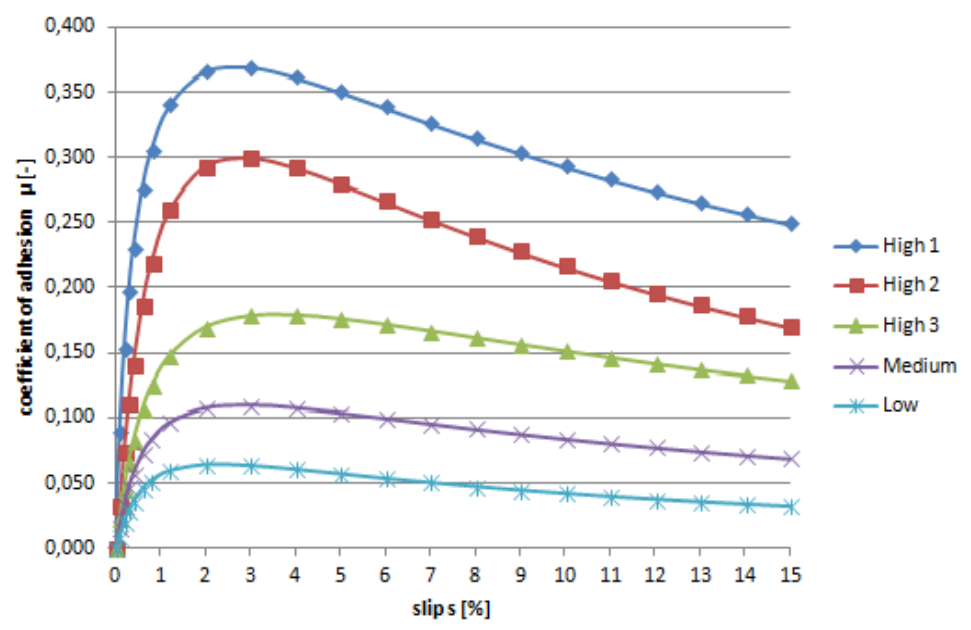

Fig. 12 Example of empirical modelling - Popovici's characteristics [2]

We decided to implement characteristics according to Popovici. These characteristics are based on a big number of measured data and their statistical interpretation, which led to the following formula.

$$
\mu=a e^{\frac{(\ln (s)-b)^{2}}{c}}
$$


Where:

$a$ - coefficient representing max. value of friction [1],

$b$ - fit parameter [1],

$c$ - fit parameter [1],

$S$ - slip [\%],

The advantages of use of this characteristics definition:

- $\quad$ based on real vehicle - real track data

- clear and simple mathematical formulation

- $\quad$ simple transfer into 2D look-up table in Matlab Simulink

Above described model is to be used for simulations leading to the ability to detect adhesion conditions of simulated drive of a train with defined variations of parameters via neural networks.

\section{EXPLOITATION POSSIBILITIES OF THE MODEL}

Primarily like any simulation model, presented model makes it possible to judge the significance and the factual effect of technical parameters whose knowledge is debatable, inaccurate and factually unrecognizable even on real work. Another advantage is the ability to explore the properties, in our case, the dynamic ones in the first instance, for the single components without the interaction or vice versa during the gradual process of their mutual interconnecting. For example, as simulated situations have shown, the torsional oscillation is bound more with the mechanical torque transmission, less adhesion and driving conditions. Last but not least, a simulation model with a detailed approach to modeling of individual phenomena is well prepared for eventual reduction of the order by experimental identification methods to the extent needed e.g. to accelerate simulation experiments, design and validation of control algorithms etc.

The simulation model in the case of objects such as the locomotive in which we investigate how to influence its traction capabilities is to exclude any experimental verification of ideas, or even building specially created prototypes. On the other hand, the suitability of the proposed method can be done with relatively solid conclusions when verified on a simulation model. This is precisely the objective of the closest stage in which we want to focus on optimizing and keeping optimal operational conditions. Due to the total or only partial non-measurability, the method based on the processing of the recorded operating data, among them is primarily the use of neural networks. The principle idea of the proposed procedure presents the following chapter. The starting point of thinking based on simulation modelling is the assumption: when the tested method has proved the best result in simulation, there is a realistic chance to expect that its functionality will be kept in real application.

\section{CURRENT DRIVING CONDITIONS EVALUATION VIA NEURAL NETWORK}

The current driving conditions are strongly influenced by the prevailing adhesion conditions determining, in combination with the current torque, the actual wheels slipping. The prevailing adhesion conditions are nowadays impossible to measure during the standard train operation. Although it is not possible to measure this quantity, its strong influence on current driving conditions can be used to determine the wheel slipping optimality. One way to evaluate the current driving conditions optimality is the mapping of learned historical driving conditions and their comparison with the ongoing state.

The process of learn of the historical driving conditions for their optimality evaluation is basically the search for the clusters defined by measured data and the driving conditions optimality. The centres of found clusters can be used as the usual driving conditions and their comparison with the ongoing driving conditions then leads to the estimated optimality. [8] 
The approach described above can be split into two parts:

- the preparation of data for training, testing and evaluation and

- cluster searching and evaluation.

The first part includes the raw measured data filtering and resampling. Moreover, the important information has to be extracted from the measured data and the final prepared data vector has to be set with the unchanging number of elements. The information extraction can be carried out by the on-line creation of the input-output model trained on the currently fed data. This approach also meets the requirement of unchanging number of elements of data vector prepared for the next processing part.

In this work, the Higher-Order Neural Unit (HONU) is considered as the mentioned model for the information extraction from given input data. The HONU is the polynomial multi-input single-output model consists of input data as the model input variables and weights as the model parameters. For any order of HONU, the model parameters remain linear. The complexity of modelled real process is captured by the combination of inputs data, where the order of higher input data combination is given by the order of HONU. For example, the input data vector for the second order HONU, usually called Quadratic Neural Unit (QNU), consists of input data values, quadratic combinations of all data values and bias. The resulting QNU then reaches to possible quadratic complexity of observed process while maintaining model parameters linear. [9][10]

The correct selection of HONU inputs variables and number of used samples of each input variable is crucial for the described approach. All operationally measured parameters connected with the power delivered to the train wheels' axes should be used as the inputs (e.g. the train weight should be included). The output variable must be directly connected with the inputs and with the current adhesive conditions (e.g. the train speed). Because the model output variable is obviously containing the dynamic properties, the close past values of the output should be used as part of the HONU inputs.

The finding of the HONU parameters, also called as HONU training, is basically the optimization problem, where the solution is the minimization of the HONU error function usually defined as the mean of squared difference between the HONU outputs and the real output variable values. The gradient based optimization algorithms, as the Gradient Descent, are usually used for the HONU training. [11]

After the first part, where the data for driving conditions evaluation are prepared, the second part comes, where the in first part prepared vector of HONU weights is fed to suitable clustering algorithm for clusters training or evaluation. The most widespread clustering algorithms are based on the K-means algorithm [12]. Instead of the K-means algorithm, the Self-Organizing Maps (SOMs) are used for clusters mapping purposes in this paper.

The SOM is a type of artificial neural network based on the unsupervised learning, where the input data are not connected with correct neural network output. The SOM transforms the n-dimensional data space to low-dimensional (typically two-dimensional) map of so-called centroids. The SOM performs the data dimensionality reduction and moreover, the trained centroids represent the input data clusters centres. In essence, the SOM can be considered as the K-means algorithm generalization. The SOM training process is based on competitive learning instead of for the Neural Networks typical back-propagation approach, and the so-called neighbourhood function is used during the training process, which ensures that the input space topological properties are preserved in the produced low-dimensional map (in data space neighbouring clusters centres are neighbours in produced map, too). One advantage of the SOM over K-means is the possible direct visualization of the data space clusters layout by the produced map plotting. [13][14] 


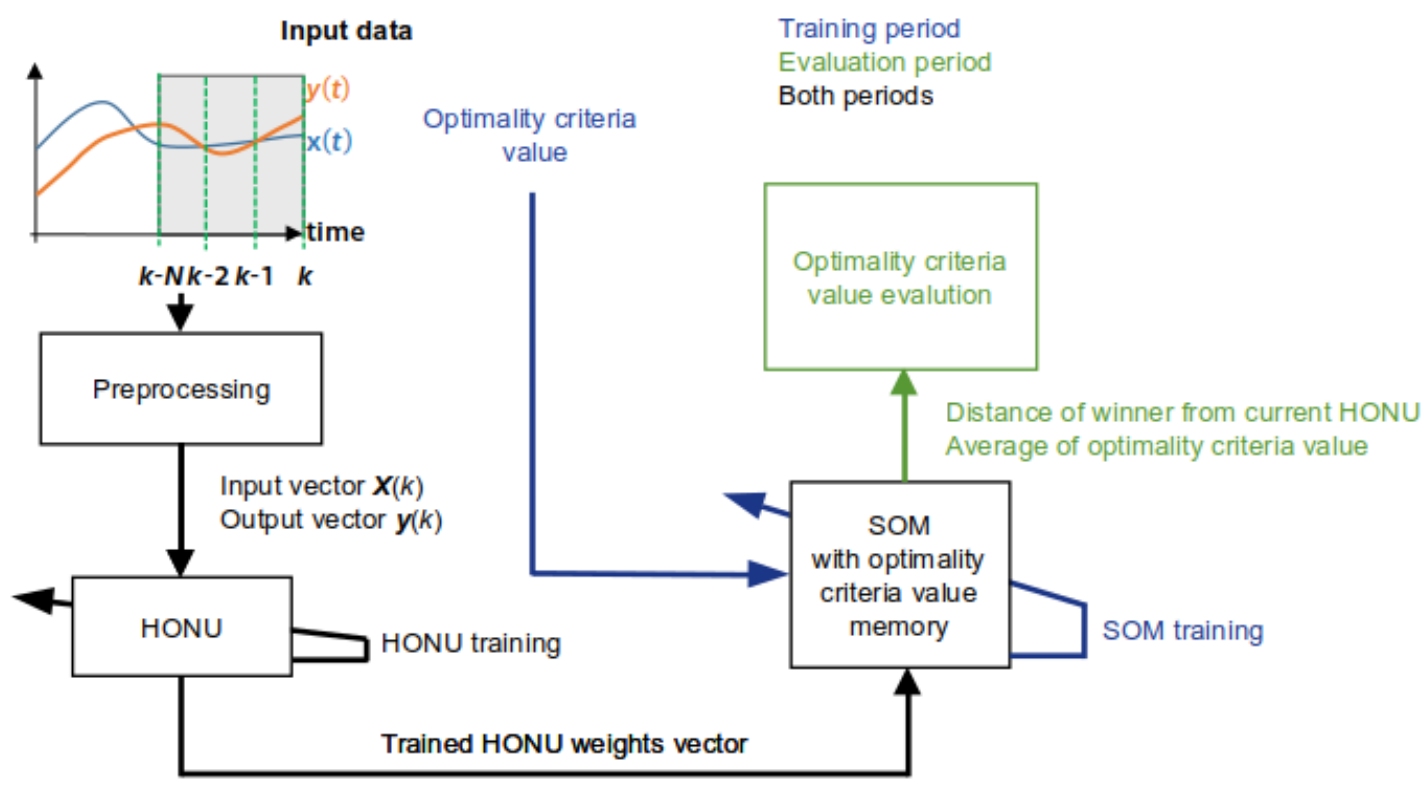

Fig. 13 Block diagram of proposed driving conditions optimality evaluation algorithm.

The basic SOM training and evaluation algorithms, based on unsupervised learning, are not connected with expected outputs, as mentioned above. In the meaning of the driving conditions the expected output is the driving conditions optimality criteria value. This expected output must be added to the SOM algorithm, for example by the connection of each centroid in the map with the average optimality criteria value provided during the training period.

Overall proposed and described algorithms are depicted in Fig. 13. In the training period the historical measured data are enriched by the estimated optimality criteria value. The measured data are correctly pre-processed and randomly fed to the well-designed HONU. After the HONU training to the currently delivered data, the trained weight parameters are used for one SOM training iteration. The centroid with feature vector closes to trained HONU weights vector is found in the SOM and is marked as winner centroid. The winner centroid is trained to new delivered data and connected with estimated optimality criteria value. The centroids adjacent with the winner centroid are trained by the neighbourhood function. During the evaluation period, the SOM training is skipped, and the average optimality criteria value connected with the winner centroid is returned as the output of the optimality evaluation algorithm.

\section{CONCLUSIONS}

The possibility to detect the adhesion conditions via neural networks and an on-line training of polynomial neural unit as an approximation of current driving conditions is supposed to be a method of optimization and effective control of a train drive. In the first step there will be a need to carry out the training of the polynomial neural unit based on data, which will be gained from simulations. Subsequently based on the gained knowledge and experience the applicability within a laboratory research or in the real vehicle service shall be revised.

\section{ACKNOWLEDGEMENT}

The creation of this paper was supported by The Czech Technical University and the related grants - No. SGS18/130/OHK2/2T/12 and SGS18/177/OHK2/3T/12. 


\section{REFERENCES}

[1] VOLTR, P. Měrení a modelování adheze kola a kolejnice. Pardubice. 2017. Habilitační práce.

[2] POPOVICI, R. I. Friction in Wheel - Rail Contacts. Enschede. University of Twente. 2010. ISBN 978-90-365-2957-0.

[3] FRIDRICHOVSKÝ, T. \& ŠULC B. Investigation of Torsional Oscillations in Railway Vehicles. MATEC Web of Conferences. 2016. Dostupné z: https://doi.org/10.1051/matecconf/20167602052.

[4] KADEŘÁVEK, P. \& PERNIČKA, J. Evropou obchází strašidlo torzních oscilací hnacích dvojkolí. Železnični magazín. 9/2013, pp. 18-22. ISSN 1212-1851.

[5] POLACH, O. Creep forces in simulations of traction vehicels runnig on adhesion limit. 6th Internatinal Conference on Contact Mechanics and Wear of Rail/Wheel Systems. 2003, June 10-13, Göthenburg.

[6] KOLÁ̌̌, J. Teoretické základy kolejových vozidel. Praha. 2009. Vydavatelství ČVUT. ISBN 978-80-01-04262-5

[7] DUB, M., KOLÁŘ, J., LOPOT, F., DYNYBYL, V. Dynamic simulation of a driving wheelset on the roller test rig , (2016) Civil-Comp Proceedings, 110

[8] OSWALD, C., Adaptivní detekce nových událostí v měřených datech pomocí kombinace SOM a HONU. ARTEP 2016 - Sbornik príspěvků, Stará Lesná, vol. 2016.

[9] GUPTA, M. Development of higher-order neural units for control and pattern recognition. NAFIPS 2005 - 2005 Annual Meeting of the North American Fuzzy Information Processing Society, 2005, pp. 395-400.

[10] GUPTA, M., BUKOVSKY, I., HOMMA, N., SOLO, A. M. G. \& HOU, Z. Fundamentals of Higher Order Neural Networks for Modeling and Simulation. Fundamentals of Higher Order Neural Networks for Modeling and Simulation, IGI Global, 2013, pp. 103-133.

[11] BUKOVSKY, I. \& HOMMA, N. An Approach to Stable Gradient-Descent Adaptation of Higher Order Neural Units. IEEE Trans. Neural Netw. Learn. Syst., vol. 28, no. 9, pp. 20222034, Sep. 2017.

[12] JAIN, A. K. Data clustering: 50 years beyond K-means. Pattern Recognit. Lett., vol. 31, no. 8, pp. 651-666, Jun. 2010.

[13] KOHONEN, T. Self-Organizing Maps, vol. 30. Berlin, Heidelberg: Springer Berlin Heidelberg, 2001.

[14] QIANQ, X. CHENG, X., \& LI, Z. A survey of some classic self-organizing maps with incremental learning. 2010 2nd International Conference on Signal Processing Systems (ICSPS), 2010, vol. 1, pp. V1-804-V1-809.

\section{DISCLOSURE STATEMENT}

The content of this paper does not infringe any copyrights, patents, know-how of anybody else or rules of the grant provider. 